811.161.1'366.58

https://doi.org/10.18485/sj.2017.22.1.29

ВИШЫА Б. ВИШЫЕВАЦ*

Универзитет у Београду

Филолошки факултет
Оригинални научни рад

Примљен: 09. 09. 2016.

Прихваћен: 15. 12. 2016.

\title{
О НЕКИМ СТАРОРУСКИМ ГЛАГОЛИМА СА ДВА ВИДА
}

\begin{abstract}
У раду се на материјалу Повести о минулим временима према Лаврентијевском летопису из 1377. године разматра категорија глаголског вида у староруском језику. Будући да је иста категорија у анализираном периоду још увек била у процесу формирања, извесним глаголима одговарајуће значење одређивао је контекст. Синхроним пресеком, али и методом преводне семантизације, размотрићемо функционисање таквих примера посматрајући стање у староруском језику и стање које затичемо у савременим језицима, те ћемо указати на специфичности које су се и до данас задржале. Стога анализу прати и лексикографска интерпретација у речницима.
\end{abstract}

Кључне речи: глаголски вид, имперфекат, аорист, староруски језик, српски језик.

\section{0. УВОД}

Категорија глаголског вида у периоду староруског језика још увек није достигла крајњу морфологизацију, односно разликовала се од стања у савременом руском језику. Ј. С. Маслов (2004: 140) наводи да је основна база за њено формирање био процес суфиксације из које се даље развија несвршени вид, а према њему, потом и свршени. У Историјској граматици руског језика

"visnja_visnjevac@yahoo.com 
(1982: 163; 175-176; 192-193; 195-197 и др.) наводи се да су у староруском језику неки од префиксалних глагола представљали чланове видских парова ${ }^{1}$. С друге стране, постојали су и глаголи који нису имали јасно обележено значење свршеног вида, тј. могли су бити и свршени и несвршени, у зависности од контекста. Прости глаголи нису имали јасна обележја глаголског вида, већ их је карактерисао тзв. общий вид. Ти глаголи су касније укључени у процес морфологизације разматране категорије. На њено коначно формирање утицало је више фактора међу којима је и доминација суфикса -ива-/-ыва-, чије се присуство знатно повећава у другој половини XIV века, затим промене у систему прошлих времена, као и формирање будућег времена².

Разматрајући глаголски вид у Повести о минулим временима (даље ПМВ), Р. Ружичка (1962: 309-310; 312) наводи да су се многи глаголи који су у савременом руском језику одређени као свршени или несвршени у староруском могли употребљавати и са једним и са другим значењем. Такве глаголе аутор разврстава у 5 група: 1) глаголи одређеног кретања (нести, ити и др.), 2) многи неизведени глгаголи на -ити (судити, купити и др.), 3) неизведени и стари атематски глаголи (речи, дати и др.), 4) глаголи видъти и стари изведени обидъти, те слышиати (можда зазьръти и держати), 5) неки глаголи са презентском основом на $-j$-.

С обзиром на горенаведене карактеристике глаголског вида које затичемо у ПМВ, многи глаголи, као што је истакао и Р. Ружичка, имали су својства нетипична за савремени језик. Главни критеријум за одабир глагола у нашој анализи био је прости - изведени, али и њихова тумачења у савременом српском језику.

Основни извор за ово истраживање чине ПМВ према Лаврентијевском летопису (даље ЛЛ) из 1377. године и одговарајући преводи на савремени српски језик Н. Косовића и В. Минића, с тим што други преводилац ПМВ није превео у целини ${ }^{3}$. Пажњу ћемо обратити и на преводе на савремени руски језик Д. С. Лихачова и О. В. Творогова. Наводе се и извесне разлике, уколико су релевантне за анализу, између ЛЛ и каснијих преписа - Тројичиног (даље TП) из XIV-XV века, Радзивиловског (даље РП) с краја XV века, Рукописа Московске Духовне Академије (даље РА) из XV века.

Први део анализе посвећен је простим глаголима који су функционисали као свршени и несвршени, односно одговарајуће значење одређивао им је

\footnotetext{
${ }^{1}$ Уп. Ружичка 1962: 314.

${ }^{2}$ Категорија глаголског вида разматра се у граматикама српског и руског језика. Посебно ћемо издвојити истраживање о двовидским глаголима у српском језику И. Грицкат: 1957-1958 и М. Спасојевић: 2015.

${ }^{3}$ Н. Косовић није превео Поуку деци Владимира Мономаха, која се сачувала у саставу ПМВ, док је исто дело код В. Минића преведено, иако опет не у целини.
} 
контекст. Такви су глаголи: речи, казати, видъти, ити, нести. У другом делу се анализирају изведени глаголи: помазати, послушати, повъдати, юбладати, растрбляти. На крају ћемо пажњу посветити и глаголима код којих акценат диференцира значење, тј. категорију вида. Такви су глаголи засыпати, nocblnати и група са кореном - $p$ zз-. Сви глаголи укључени у анализу, изузев казати и последње наведне групе, јављају се у форми имперфекта и аориста, којима ПМВ обилује, а како је исте облике српски језик сачувао, управо он ће нам омогућити одговарајућу реконструкцију.

Анализа започиње синхроним пресеком двају језика - староруског и савременог српског, али ћемо указати и на стање у савременом руском језику, док ће нам метод преводне семантизације омогућити одговарајућу интерпретацију староруских облика. Осим тога, приликом анализе глаголских форми указаћемо и на различита тумачења у речницима.

Категорију глаголског вида, тј. несвршене, свршене, као и двовидске глаголе, условно ћемо тако називати, са становишта савременог језика, јер у периоду староруског језика, односно анализираног споменика, они нису имали строго таква разграничења. Испитивана категорија крајњу морфологизацију достигла је нешто касније.

\section{1. ПРОСТИ ГЛАГОЛИ У СТАРОРУСКОМ ЈЕЗИКУ}

У првом делу истраживања анализирају се глаголи: речи, казати, видъти, ити, нести. Наводићемо примере у којима су исти глаголи, изузев казати, употребљени најпре у форми имперфекта, а затим аориста. Овакав принцип прати и остале глаголе, изузев групе са кореном -pъз-.

Како смо већ истакли у уводном делу, највећи део простих глагола првобитно није карактерисала категорија вида, односно није улазио у састав видских парова.

(1) аще которыи брать оумышлАше ити из манастырА и оузрАше и пришедъ к нему

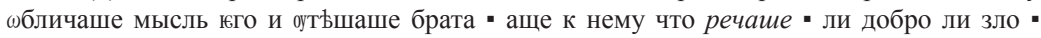
сбудАшетсА старче слово (ПВЛ, 190)

(1a) Ако ко од браће помишљаше да иде из манастира, и (Јеремија) види то, пришавши му, раскринкаваше замисао његову и тјешаше брата. Ако ли коме шта предсказиваше - добро или лоше - старчева се ријеч обистињаваше. (ПМљ, 117)

(2) ре - же кнАзь Печенъжьскии къ Прьтичю - буди ми другъ створю - (ПВЛ, 67) (ПМљ, 41)

(2а) Рече кнез печенешки Претичу: „Буди ми пријатељ”. Он рече: „То ћу и бити”. 
За глагол речи $u^{4}$ у речницима налазимо да се употребљава са значењем свршеног, али и несвршеног вида ${ }^{5}$ (СДРЯ, Х, 374-380; Срезневский, III, 118-120; СРЯ, XXII, 157-158; Стсл, 580-581). Видимо да је српски преводилац употребио имперфекат глагола предсказивати, а које је једно од значења глагола речи као несвршеног (СДРЯ, X, 378). RJAZU наводи да је глагол рећи у неким облицима несвршеног вида, као и да постоје примери у којима је тешко утврдити његову видску вредност. Тако исти речник наводи примере за имперфекат из старијих споменика српског језика (RJAZU, XIII/58, 811). Осим облика имперфекта, глагол речи у староруском језику имао је и форме радног и трпног партиципа садашњег времена рькА, рекуще / рькуще, рекомыи, а које налазимо и у ПМВ. Исти глагол у формама радног партиципа садашњег времена имао је значење несвршеног вида (ИГРЯ 1982: 338-339). Такви облици јављали су се и у старијим спомениц има српског језика (RJAZU, XIII/58, $812)$, а форма некадашњег партиципа среће се и данас у изразима боље рекућ, тако рекућ(u) (РМС, $\mathrm{V}, 522)$. У речнику руских говора глагол речи́ одређује се као несвршени (СРНГ, XXXV, 81). Осим самог облика речаше, видимо да се у читавом контексту налази имперфекат. Пошто је током историјског развоја руског језика дошло до упрошћавања система прошлих времена и до доминације једног облика за исказивање прошлих радњи, приликом превођења староруских форми размотрићемо само категорију глаголског вида. У преводу на руски језик за имперфекат је употребљен глагол несвршеног вида: предрекал, а за аорист - свршени вид: сказал, ответил (ПВЛ ДЛ, 219; $168 ;$ ПВЛ $\left.\mathrm{OT}^{6}\right)$.

(3) и пришедшю єму • нача впрашати єго Володимерь • то въдђ ла вы рота • многажды бо ходивши роть - воєвасте Русскую землю - то чему ты не казаше $\mathrm{cH}^{-}$въ своихъ и роду своюго не преступати роты - но проливаше - кровь хь $\boldsymbol{~} \cdot$ ньску• (ПВЛ, 279)

(3а) И када дође к њему, поче га испитивати Владимир: „Знај, то вас је задесила велика клетва! Јер, много пута давши клетву, робисте Руску земљу. Зашто ти не каза синовима својим и роду своме - да не газите клетву, већ проливасте крв хришћанску? [...]" (ПМљ, 160)

(4) башеть бо сиць • на лици єму срамнии оудове $・$ иного нелзђ казати срама ради • (ПВЛ, 164)

(4а) Бијаше овако: на лицу му срамни удови; друго је немогуће казати због срамоте. (ПМљ, 102)

\footnotetext{
${ }^{4}$ У речнику староруског језика као посебне лексикографске јединице наводе се глаголи речи ${ }^{1}\left(\right.$ рещз $\left.{ }^{1}\right)$, рекоу, речеть и реч $u^{2}\left(\right.$ рещз $\left.u^{2}\right)$ рькоу, рьчеть. Оба глагола одређују се са значењем свршеног и несвршеног вида.

${ }^{5}$ Речници староруског језика, за разлику од старословенског, не наводе експлицитно ознаке за категорију глаголског вида, већ њихово значење тумачимо на основу превода на савремени руски језик. У неким случајевима, што ћемо видети у даљем излагању, акцентом староруских форми указује се на разлике.

${ }^{6} \mathrm{O}$. В. Творогов, Повесть временных лет. «ttp://lib.pushkinskijdom.ru/Default.aspx?tabid=4869〉 8. 05.2016.
} 
У РП и РА наведен је облик не училъ. Глагол казати речници тумаче на различите начине - у једнима вид није диференциран, тј. може се употребљавати са значењем како свршеног тако и несвршеног вида (Срезневский, I, 1174-1175; CРЯ, VII, 17), а у другима је одређен само као несвршени (СДРЯ7, IV, 186-187; Стсл, 280). У етимолошком речнику словенских језика стоји да је прасловенски глагол *kazati дуративни, као и да је у једним словенским језицима несвршеног вида (словеначки, чешки, словачки, доњолужичкосрпски, горњолужичкосрпски, пољски, украјински, белоруски), док је у другима свршеног вида (српски, бугарски, македонски) (ЭССЯ, IX, 168-170). У руском језику глагол каза́ть несвршеног вида има значење показывать ${ }^{8}$ (ТСРЯ, 315), док је глагол сказать свршеног вида, који такође налазимо у ПМВ 9 . С друге стране, несвршени вид глагола каза́ти забележен је у руским говорима, док глагол каза́ть, који је, поред говорить, сообщать, рассказывать, као једно од значења, сачувао старо учить, указывать, советовать, може бити и свршеног вида са значењем сказать, али се одређује и као несвршени и свршени: велеть, приказать (СРНГ, XII, 312-313). Када је реч о глаголу казати у српском језику речници показују да се употребљава и као свршени и као несвршени ${ }^{10}(\mathrm{PMC}$, II, 626; PCAHУ, IX, 67-69; RJAZU, IV, 911-920). RJAZU га одређује на следећи начин: „Glagol je isprva bio imperfektivan, tako je u ostalijem slavenskijem jezicima; u našemu je (i u bugarskome) postao i perfektivan: po Vuku je perfektivan u svijem oblicima, osim prezenta u kojem može biti i imperfektivan; ali ne samo u starije već i u naše vrijeme može se naći impf. kâzâh $i$ ger. praes. kážûći, teško je poznati u primjerima jeli jedno ili drugo; [...]" (RJAZU, IV, 911). Исти речник наводи да је једно од његових значења саветовати, учити (RJAZU, IV, 913), какво је било и у староруском језику, али и у савременим руским говорима. Српски преводилац је, очито под утицајем свршеног вида, за наведену форму имперфекта употребио аорист глагола казати, док су руски преводиоци изабрали глагол несвршеног вида: не учил (ПВЛ ДЛ, 257; ПВЛ ОТ). Осим тога, у Ипатијевском летопису, који је О. В. Творогов користио приликом превођења, стоји као и у РП и РА: не училъ. У преводу на савремени руски језик за глагол казати са значењем свршеног вида употребљен је глагол сказать исте видске карактеристике (ПВЛ ДЛ, 209; ПВЛ ОТ).

\footnotetext{
${ }^{7}$ Пошто СДРЯ наведени глагол одређује искључиво са значењем несвршеног вида и наш други пример са глаголом казати протумачен је на исти начин, док смо га ми овде окарактерисали као свршени.

${ }^{8}$ Глагол показывать наводи се као синоним за глагол казать само у једном значењу, односно исти глагол одређује се као несвршена варијанта за: показать, 1. кого-что кому. Дать возможность увидеть кого-что-н., убедиться в чём-н., научиться чему-н. (ТСРЯ, 681)

${ }^{9}$ Глагол сказати спада у групу глагола са двојаком променом у презенту, попут глагола помазати (види т. 2, пр. 11)

${ }^{10}$ Уп. Грицкат 1957-1958: 75; 95; 98; 109; Спасојевић 2015: 143-145 .
} 
(5) по Бж ью же оустрою • в се же времА разболь - Володим • ръ ()иима и не видаше ничтоже • [и] тужаше велм • [и не домышлашет"ь "- что створи•]• (ПВЛ, 111)

(5а) По Божијем промислу разболио се у то вријеме Владимир од очију, и не виђаше ништа, и тужаше веома, и не домишљаше се шта да чини. (ПМљ, 69-70)

(5б) По божанскоме промислу, разбоље се у то вријеме Владимир од очију, и не виђаме ништа. И силно је био тужан, и није знао шта ће чинити. (ОССРК, 18)

(6) и приде въ Словђни • идеже нынъ Новъгородъ - и видъ ту люди суща •- како

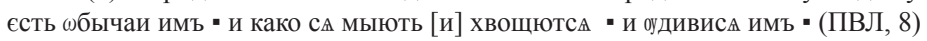

(6а) И дође у Словене, гдје је данас Новгород, и видје ту тамошње људе - какав им је обичај, и како се умивају и шибају, и зачуди им се. (ПМљ, 8)

(6б) И стиже код Словена, тамо гдје је данас Новгород, и видје људе који тамо живе - какав им је обичај и како се купају и шибају, и зачуди им се. (ОССРК, 10)

И глагол видъти имао је способност исказивања значења оба вида, почевши од старословенског, преко староруског, па до савременог српског језика ${ }^{11}$ (Стсл, 114-115; Срезневский, I, 256-257; СРЯ, II, 174; PMC, I 369-370, PCAHУ, II, 589-590; RJAZU, XX/86, 814-836). Међутим, речници староруског језика нису уједначени у интерпретацији наведеног глагола, те се у једном он тумачи, попут претходно наведеног казати, само са значењем несвршеног вида (СДРЯ, I, 420-423), а такав је и у савременом руском језику (ТСРЯ, 91). Наши примери показују разлику, тј. и свршени вид глагола ${ }^{12}$. Овде бисмо морали указати на акценат, те би имперфекат гласио не вйђа̄ще. У преводу на руски језик у првом примеру употребљен је глагол са значењем несвршеног вида: не видел, а у другом свршеног: увидел (ПВЛ ДЛ, 187; 145; ПВЛ ОТ).

У оквиру наше анализе размотрићемо и глаголе кретања ити и нести који, као прости глаголи, нису имали прецизно одређен вид.

Анализирајући систем прошлих времена у ПМВ, Г. Ј. Симина (1959: 49-50) наводи да глаголи као што су нести, бежать и др. могу означавати завршену радњу. Исти аутор каже: „Наличие таких конструкций, где в качестве однородных сказуемых выступают формы аориста от длительных и недлительных основ, отчетливо обнаруживает известное безразличие к виду, обилие в древнерусском языке глаголов недостаточной видовой дифференцированности" (Симина 1959: 50).

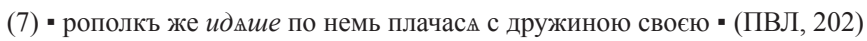

(7а) А Јарополк иђаше за њим са дружином својом плачући: [...] (ПМљ, 124)

${ }^{11}$ И. Грицкат (1957-1958: 70-71) и М. Спасојевић (2015: 122) наводе да је глагол видети у значењу имати чуло вида само несвршен.

${ }^{12}$ Глаголи речи и видъти веома су чести у ПМВ у форми аориста, у којима су употребљени са значењем свршеног вида. С друге стране, њихов несвршени вид огледа се, поред имперфекта, у формама радног и трпног партиципа садашњег времена, што је случај и са глаголом казати: - коже створи н ${ }^{-}$бса землю море • вс оучими єсммы • пути пока нью - (ПВЛ, 152). О формама партиципа са значењем несвршеног вида глагола речи већ смо говорили (в. пр. 1). 
У наведеном примеру староруски имперфекат преведен је на српски језик истим обликом, а у руском језику употребљен је глагол несвршеног вида шел (ПВЛ ДЛ, 224; ПВЛ ОТ).

Глагол ити $u^{13}$ у форми аориста са значењем свршеног вида, посебно када су у питању сукцесивне радње, често срећемо у ПМВ ${ }^{14}$.

(8) и варивше - ша кнАзи Печенђзьстии - и подивишасА - и поимще тали сво "- и

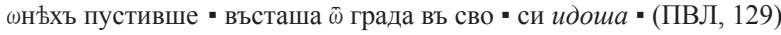

(8а) И, сваривши, једоше кнезови печенешки, и зачудише се. И узеше своје таоце, а оне (бјелогородске) пустише, (и) дигоше се од града и одоше натраг. (ПМљ, 80-81)

Аорист глагола свршеног вида поидоша наведен је у РП и РА. Дакле, каснији преписи дају форме ближе савременом језику ${ }^{15}$. И руски преводиоци употребили су префиксални глагол свршеног вида пошли (ПВЛ ДЛ, 195; ПВЛ ОТ). Речник старословенског језика наведени глагол тумачи као несвршени и свршени (Стсл, 275-276), док је у речницима староруског језика одређен као несвршени (СДРЯ, IV, 178-181; Срезневский ${ }^{16}$, I, 1023-1024; СРЯ, VI, $356-357)$.

И глагол нести могао је бити употребљен са значењем несвршеног, али и свршеног вида.

(9) и бњжащю єму нападе на нь бњсъ - и ра-слабђша ${ }^{17}$ кости єго- не можаше съдђти [на кони]· и несАхуть и на носильхь - (ПВЛ, 144-145)

(9a) И када је он бјежао, нападе на њега ђаво, и ослабише удови његови: не могаше да сједи на коњу, па га носише на носилима. (ПМљ, 90)

(10) и оубиша Асколда и Дира - [и] несоши на гору и погребша и на горђ - (ПВЛ, 23)

(10а) И убише Аскољда и Дира и однесоше на гору, и сахранише их на гори [...] (ПМљ, 15)

(10б) И убише Аскољда и Дира, однијеше их на брдо и сахранише: [...] (ОССРК, 13)

Српски преводилац је за староруски имперфекат употребио аорист несвршеног вида, уместо имперфекта ношаху. У преводу на савремени руски језик употребљен је глагол несвршеног вида несли (ПВЛ ДЛ, 201; ПВЛ ОТ).

На могућност тумачења глагола нести и као свршеног указују нам два староруска речника (СДРЯ, V, 362; СРЯ, XI, 308), док је у трећем и речнику старословенског језика само несвршени (Срезневский, II, 426; Стсл, 374).

\footnotetext{
${ }^{13} \mathrm{O}$ значењу свршеног вида глагола ити у старословенском језику Н. Ван Вијк каже: [...] „Кирилл и Мефодий в своем переводе евангелия использовали простой глагол iti во всех тех случаях, где в более позднюю эпоху было бы отдано предпочтение приставочному ро-іti” (Ван-Вейк 1962: 244).

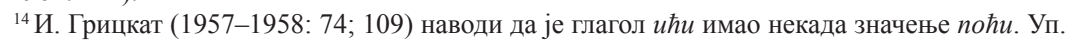
Спасојевић 2015: 141-142.

${ }^{15}$ УП. Ружичка 1962: 308.

${ }^{16}$ Прво објашњење дато је на грчком језику, а у осталим глагол има значење несвршеног вида.

17 Знак - указује на прелазак на нови лист, односно обратну страну листа у оригиналном рукопису.
} 
RJAZU глагол nesti дефинише на следећи начин: „Glagol je ovaj sam, bez prijedloga u našem jeziku svagda bio rijedak, kao što je rijedak i danas. [...] Kašto se nalaze oblici, koji odgovaraju oblicima na pr. donijeti, donijeh, donijela [...]" (RJAZU, VIII/35, 88). Дакле, наведени прости глаголи кретања могли су се употребљавати и са значењем свршеног вида, а које је одређивао контекст ${ }^{18}$. И руски преводиоци, у другом примеру, употребили су глагол свршеног вида отнесли (ПВЛ ДЛ, 150; ПВЛ ОТ), а одговарајућу форму аориста видимо у српским преводима.

О глаголима са перфективним значењем а имперфективним ликом у српском језику писао је Р. Маројевић (2008: 179-198) анализирајући језик П. II

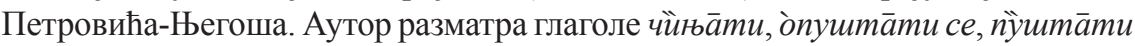
(ce), вйҺ̄̄ти (ce), чйја̄ти (се), о̀блачйти (се) од којих су неки употребљени у форми имперфекта, али са значењем аориста, на пример:

Чудне бруке [бруіке̄], грдне [грิдне̄] мјешавине [мјеेшавине̄]! / Чујасте ли [чйја̄стели] како се појаше [пӧја̄ше]? (Маројевић 2008: 187)

\section{2. ИЗВЕДЕНИ ГЛАГОЛИ У СТАРОРУСКОМ ЈЕЗИКУ}

Други део анализе посвећен је изведеним глаголима: помазати, послушати, повђдати, юбладати, растрђлАти.

Како наводи J. С. Маслов (2004: 139), приликом формирања категорије глаголског вида префиксација глагола није подразумевала и појаву свршеног вида, већ је дати процес представљао само предуслов за њен даљи развој. Наши примери показаће да су се извесни остаци сачували у староруском језику, тј. да неки префиксални глаголи још увек нису били одређени искључиво као свршени.

(11) аще кто коли принесаше дђтищь боленъ - кацЊмь любо недуго • одержи •-

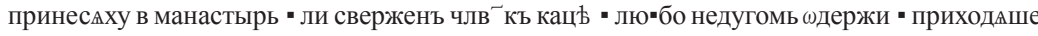
в манастырь къ блж ному Өешдосью - повельваше сему Дамь - нъ млт ву створити болАщему $\cdot$ и абьє створАще молитву $\cdot$ и масломь помазаше $\cdot$ и приимаху ицбленыє приходิщии к нему • (ПВЛ, 189)

(11a) Ако ли ко донесаше у манастир к блаженом Феодосију, (тада Феодосиј) наређиваше овоме Дамјану да очита молитву над болесником, и овај одмах читаше молитву и уљем мазаше, и примаху исцјељење они који долажаху к њему19. (ПМљ, 117)

\footnotetext{
${ }^{18}$ „Ако се о трајној радњи (чије је име - имперфективни глагол) контекстом или ма како друкчије семантички изрекне да је она цела (истакла - И. Г.) извршена, да је од слике акције постало сазнање, спомен о акцији, онда се глаголу придао, у суштини, онај „декор” који претставља карактеристику перфективног глагола. Главна карактеристика се променила у смислу прелаза од имперфективности ка перфективности" (Грицкат 1957-1958: 95).

${ }^{19} \mathrm{y}$ српском преводу недостаје део наведеног фрагмента.
} 
(12) [и] Бу - повельвшю сступишасА $\omega$ ни • [горы велики •] • токмо не ступишасА

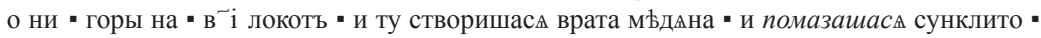
(ПВЛ, 236)

(12a) [...] и, по Божијој заповијести, склопише се за њима планине велике, само се не склопише за њима планине на 12 лаката (ширине), и ту се створише врата мједена и намазаше се асинхитом; [...] (ПМљ, 143)

Глагол помазати могао је бити несвршеног и свршеног вида, али га је карактерисала и двојака промена у презенту: помазаю, помазањии указује на несвршени вид, а помажоу, помажеши на свршени вид (СДРЯ ${ }^{20}$, VII, 120-122; CPЯ, XVI, 291-292; Срезневский ${ }^{21}$, II, 1155; Стсл, 474-475). Како се наводи у Историјској граматиии руског језика (1982: 167-168), додавањем суфикса за имперфективизацију - $a-/ /-a j$ - глаголима попут помазати, помажуть (са суфиксом $-a-/ /-* j-)$ формирали су се тзв. имперфективи. Тако су се појавили паралелни облици у садашњем времену - са једне стране су постојале форме као што је помажю, које нису имале јасна обележја глаголског вида, односно касније су постале перфективне, а са друге - облици попут помазаю употребљавали су се у имперфективном значењу. Наспрам две варијанте у презенту стајао је један облик за форме које су се градиле од основе прошлог времена.

За староруске примере у преводу на савремени српски језик употребљени су исти облици, тј. имперфекат глагола несвршеног и аорист глагола свршеног вида, док је у руском језику разлика искључиво у категорији вида: мазал и помазались, односно помазали (ПВЛ ДЛ, 219; 246; ПВЛ ОТ). У РП и РА у другом наведеном примеру употребљен је облик помаза.

(13) и н-ре - Адамъ скотомъ и птицамъ имАна • звъремъ и гадомъ • и самъма анг `лъ

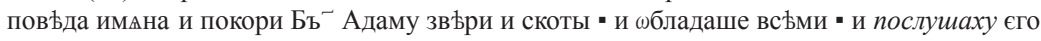
- (ПВЛ, 88)

(13a) И даде Адам стоци и птицама имена, звијерима и гмизавцима, и самим анђелима даде имена. И потчини Бог Адаму звијери и стоку, и овлада (он) свима, и слуиаху га. (ПМљ, 55-56)

(14) видъвъ же волъхвъ и ре - цр - ви - $\omega$ цр $^{-}$ю погуби - имать погубити всего Єюпта - и не послуша єго цр ${ }^{-}$ь " но паче повелъ не погубити дьтии Жидовьски • (ПВЛ, 94)

(14a) Видјевши пак то врач, рече цару: „О царе! Погуби дијете ово; ако га не погубиш, он ће да погуби сав Египат”. И не послуша га цар, него нареди чак да се (више) не убијају дјеца јеврејска. (ПМљ, 59)

У наведену групу спада и глагол послушати 22 (СДРЯ, VII, 252-254; Срезневский, II, 1240-1241; СРЯ, XVII, 190-191; Стсл, 482-483). Старорус-

${ }^{20} \mathrm{У}$ наведеном речнику код глагола помазати у оквиру свршеног вида наведен је наш пример са формом имперфекта, док смо му ми одредили значење несвршеног вида.

${ }^{21}$ Код истог глагола са значењем несвршеног вида И. И. Срезњевски наводи и акценат: помаза̀ти, помаза̀ю.

${ }^{22}$ Свршени вид наведеног глагола огледа се и у форми презента: аще не послушаєть тебе цр $^{\sim}$ ь Еюпетьски - побью и всьми чудесы моими - (ПВЛ, 95). С друге стране, несвршени вид 
ки имперфекат на савремени руски језик преведен је глаголом несвршеног вида: слушали, а аорист глаголом свршеног вида: послушал (ПВЛ ДЛ, 178; 180; ПВЛ ОТ).

Глаголи помазати и послушати претрпели су перфективизацију ${ }^{23}$, те су у савременом руском књижевном језику свршеног вида, док су глаголи мазать и слушать несвршени (ТСРЯ, 424; 693; 704; 900), што смо видели у преводу. Свршеног вида су исти глаголи и у српском језику: помазати, послушати (PMC, IV, 672; 754; RJAZU, X/45, 665-666). Међутим, у RJAZU наводи се следеће: „POSLUŠATI, poslušam, impf. prema pf. poslušati. Da je danas impf. poslušati u običaju, bio bi mu akc. poslúšati, pòslûšâm prema pf. pòslušati, pòslušâm; [...]" (RJAZU, X/46, 945). Исту појаву налазимо и у руским говорима послу́шать - свршени вид, послуша́ть - несвршени вид, а истог је вида и у повратној форми - послуша́ться (СРНГ, ХХХ, 182). Више о улози акцента у одређивању глаголског вида биће речи у даљем тексту (види т. 3).

(15) (ному же ньчимъ заложити • вступль ногама босыма - ста на пламени • дондъже изгорђ пещь [и] излъзе - и ина многа повъдаху ш немь - (ПВЛ, 196)

(15a) А онај не имаше чиме да запуши рупе, и стаде босим ногама на пламен, и стајаше на пламену док не изгорје пећ, и тек сада сиђе. И многошта друго причаху о њему, [...] (ПМљ, 121)

Са значењем свршеног и несвршеног вида у староруском језику био је и глагол повђдати (СДРЯ, VI, 477-478; СРЯ, XV, 141-142). И. И. Срезњевски за исти глагол даје објашњење: разсказать, сообщить, иако су наведене форме имперфекта и радног партиципа садашњег времена у којима је глагол употребљен са значењем несвршеног вида (Срезневский, II, 1006-1007). С друге стране, речник старословенског језика наводи да се исти глагол употребљава као несвршени (Стсл, 457). У нашим примерима указаћемо на разлике. Тако наспрам имперфекта повъдаху имамо аорист повъда у горенаведеном примеpy (пр. 13). У RJAZU povijedati одређује се као несвршени према свршеном povidjeti, али се указује и на могућност употребе у значењу свршеног вида, при чему се јављају и примери у којима је тешко утврдити да ли је исти глагол употребљен као несвршени или као свршени (RJAZU, XI/48, 261-263). На савремени руски језик имперфекат је преведен глаголом несвршеног вида рассказывали, а аорист - глаголом свршеног вида дал (ПВЛ ДЛ, 222; 178; ПВЛ ОТ).

може бити употребљен такође у форми презента, а свршени вид у форми императива: и ре ळррину ஸ̃ себе призову ины лю - иже мене послушають - (ПВЛ, 98); се же поручаю в со|бе мњсто столь старђишему сн ${ }^{-}$у моєму и брату вашему ИзАславу Кыєвъ - сего послушаите • ко • послушасте мене - (ПВЛ, 161).

${ }^{23}$ Током XVIII века овакви имперфективи са променом попут помазаю готово нестају из употребе, а замењују их облици са продуктивним суфиксом -ива- (ИГРЯ 1982: 264). 
(16) И посемь възратиша • в землю свою и не бъ оу нихъ цр ${ }^{-} \mathrm{A} \cdot$ но архиєрђи (бладаху ими • до Ирода иноплеменьник • иже

(16а) И затим се вратише у земљу своју, и не имађаху цара, већ архијереји владаху њима до туђинца Ирода, који завлада њима. (ПМљ, 64)

Глагол обладати у старословенском језику одређује се, попут повђдати, као несвршени, а такав је и у речнику И. И. Срезњевског (Стсл, 392; Срезневский, II, 514). Међутим, други речници староруског језика истичу двовидске карактеристике истог глагола, на шта нам указују и наши примери ${ }^{24}$ (СДРЯ, V, 486-487; CРЯ, XII, 64). Глагол обладать у руском језику задржао је значење несвршеног вида (ТСРЯ, 537). На двовидске особине указује нам RJAZU: „OBLADATI, obládati, òblâdâm, pf. i impf. [...] Od ob-vladati (v je iza b po zakonu ispalo, ali ima $i$ obvladati, [...]) [...] Glagol je u novija vremena pf., u starija je često impf." (RJAZU, VIII/36, 378). Други речници српског језика глаголе обладати и овладати тумаче као свршене (PMC, III, 861; 896; PCAНУ, XVI, 287; 531-532). У истом примеру поред имперфекта 3. лица једнине видели смо у пр. 13) имамо аорист истог глагола (блада, са значењем свршеног вида. Руски преводиоци су за имперфекат употребили глагол несвршеног вида властвовали, док су аорист превели конструкцијом са радним партиципом прошлог времена ставщего над ними властвовать (ПВЛ ДЛ, 183; ПВЛ ОТ).

(17) а ихже имахоу пльнникы. Фвђхъ посеках - дроугиа же м чахоу. ины - же растрелАхоу. а дроугы - в море вметахоу. и ина многа [зла] творАхоу Роусь Грекомъ. єликоже ратнии творАть (ПВЛ $\left.{ }^{25}, 30\right)$

(17a) А те, које заробише, ове посјекоше, друге мучаху, неке постријељаше, а друге у море бацише, и многа зла чињаху Руси Грцима, као што непријатељи раде. (ПМљ, 18)

(17б) А оне које заробише, једне посјекоше, друге мучише, неке опет убише стријелама, а неке побацаше у море, и много другога зла учинише Руси Грцима, како то обично чини непријатељ. (ОССРК, 13)

(18) а заоутра по зори повњсиша ВасилА - и ЛазарА - и растрђлАша стрђлами Василковичи • и идоша $\tilde{\omega}$ града • (ПВЛ, 268)

(18а) А сутрадан, у зору, објесише Васиљка и Лазара, и стријељаше их стријелама Васиљковичи, и одоше од града. (ПМљ, 153)

У Историјској граматици руског језика (1982: 245) наводи се да је глагол расстр Ђляти сачувао значење оба вида све до краја XVII века. Његов двовидски карактер потврђују и речници (СДРЯ, X, 230-231; СРЯ, XXII, 66). У речнику И. И. Срезњевског, међутим, оба наведена примера налазе се у оквиру исте

${ }^{24}$ Употребу наведеног глагола са значењем несвршеног вида потврђују и облици радног партиципа садашњег времена у предикатској и атрибутској функцији: и бъ облад 24); поставлю оуношю кнАзА имъ • и ругателА Фбладающ • ими • (ПВЛ, 140). У другом примеру контекст указује да је реч о радњи која предстоји, због чега би радни партицип имао значење будућег времена: који ће владати.

${ }^{25}$ У ЛЛ недостаје део текста од 14. до 21. листа, те се ПМВ наводи према РП. 
лексикографске јединице: растр Ђл ти - разстрђлять (Срезневский, III, 91). У савременом руском језику наведени глагол је свршеног вида, а несвршеног вида је глагол расстреливать ${ }^{26}$ (ТCPЯ, 814). RJAZU за глагол rastrijed'ati наводи: „RASTRIJEĎATI, rastrijed'am, impf.pf. rastrijeliti; sasvim ustrijeliti; [...]” (RJAZU, XIII/56, 319). У аналогним случајевима састављачи речника стављали cy „impf. prema $p f . ”$. Овде је предлог према изостављен, али претпостављамо да аутор наведене лексикографске јединице исти глагол тумачи као несвршени ${ }^{27}$. Оба српска преводиоца форму имперфекта превела су аористом свршеног вида. Осим тога, видимо да је В. Минић све примере имперфекта превео аористом, при чему једном несвршеног вида, док је Н. Косовић комбиновао ова два облика. Контекст нам указује да није реч о радњама које су се десиле једном. Тако бисмо и овде могли употребити имперфекат стрељ $a x y^{28}$, па би наведени фрагмент гласио: А оне које поробљаваху, ове сеиијаху, друге пак мучаху, треће стрељаху, а друге у море баиаху. Руски преводиоци су имперфекат заменили глаголом свршеног вида застрелили, а за аорист су употребили свршени вид некадашњег двовидског глагола расстреляли (ПВЛ ДЛ, 153; 252; ПВЛ ОТ). У ТП наводи се имперфекат растляху.

\section{3. АКЦЕНАТСКО ДИФЕРЕНЦИРАЬЕ КАТЕГОРИЈЕ ГЛАГОЛСКОГ ВИДА}

У оквиру наше анализе осврнућемо се и на глаголе код којих акценат одређује категорију вида. Такви су староруски глаголи посыпа́ти (несвршени вид) - посьі́nати (свршени вид) и засыпа́ти (несвршени вид) - засьі́nати (свршени вид).

(19) и сице по чивъ бра•ю - цЊлова въсА по имени • и тако изидАше из мон $\cdot$ стырА - взима" мало коврїжекъ- [и] вшедъ в печеру • и затворАше двери печерђ и засыпаме перстью • и не гл ше никомуже $\bullet($ ПВЛ, 185)

(19a) И овако поучивши братију, поздрави он свакога поименично, и затим одлазаше из манастира, узимајући мало хљебаца, и, ушавши у пећину, затвараше врата пећине и засипаше их земљом, и не говораше ни са ким; [...] (ПМљ, 114)

\footnotetext{
${ }^{26}$ У XIV веку појављује се нови глагол са значењем несвршеног вида расстрђливати, који се задржао до данас (ИГРЯ 1982: 245).

${ }^{27}$ Наводи се пример из језика Ш. Менчетића: „Do suz me ucvid'a ńe grlo od sniga, a ličcem rastrid'a jak strilac biliga".

${ }^{28}$ Недоследности приликом тумачења глагола стрељати налазимо и у речницима српског језика - у једном је одређен као глагол несвршеног вида, а такав је био у старословенском и староруском (RJAZU, XVI/70, 739-741; Стсл, 631; Срезневский, III, 570-571; CPЯ, XXVIII, 159). C друге стране РМС исти глагол одређује као двовидски (PMC, VI, 25). Уп. Грицкат 1957-1958: 82; 110; Спасојевић 2015: 167.
} 
(20) приникъши (лльга и ре• имъ добра ли вы честь (нни же рђша пущи ны Игоревы смр $^{-}$ти и повель засыпати • живы • и посылама • (ПВЛ, 56)

(20a) Олга се нагну и рече им: „Да ли вам се допада част?” Они пак рекоше: „Више од Игорове смрти". И нареди (Олга) да их заспу живе, и засуше их. (ПМљ, 34)

(20б) И, завиривши у јаму, запита их Олга: „Је ли вам добра част?” А они одговарају: „Опрости нам Игорову смрт”. И наредила је да их живе затрпају, и засуше их. (OCCPK, 15)

Први пример тумачимо као имперфекат несвршеног вида, док је у другом примеру реч о глаголу свршеног вида, употребљеном у форми аориста у староруском, као и у савременом српском језику, а исте је видске карактеристике и инфинитив засыпати. У истом примеру у РП наводи се облик засыпаша, док је у РА засыпаше. У речнику староруског језика за глагол засыпати стоји да има значење засbі́namb, а примери које смо ми овде навели налазе се у истој одредници (СДРЯ, III, 349). Међутим, код глагола посыпати истиче се разлика, при чему је и промена другачија - посыпати ${ }^{1}$, посыплю, -леть: посы́пать; посыпатиㄴ, посыпаю, -ють: посыпа́ть (СДРЯ, VII, 329). У другом речнику наводе се две лексикографске јединице, при чему се акцентују форме у савременом руском језику, у којем је сачуван исти однос-засьі́namb, nocbínams сврш. вид, засыnámb, nocbınámь несврш. вид (СРЯ, V, 311-312; XVII, 275-276; ТСРЯ 267; 707; ИГРЯ 1982: 264). И. И. Срезњевски акцентом истиче видску разлику, па nocbıǹmu има значење несвршеног, а посы̀nати свршеног вида, али се разлика огледа и у промени посыпаю наспрам посыплю (Срезневский, II, 1281-1282). На такве разлике исти аутор указивао је и код глагола помаза̀ти, помаза̀ю29. Исти аутор не наводи глагол засыпати. У преводу на руски језик употребљени су облици засыпал и засыпали, без акценатске ознаке, иако нам контекст јасно указује на одговарајуће значење (ПВЛ ДЛ, 217; 164; ПВЛ ОТ).

О акценатском диференцирању категорије глаголског вида у староруском језику можемо говорити у оквиру групе глагола са кореном - $p$ Łз-, с тим што у речницима наилазимо на различита тумачења, а овде ћемо издвојити глаголе обрђзати и зарђзати. Тако се у једном речнику за први глагол указује на акценатску разлику, тј. категорију вида - обръзати, обрњжу свршени вид, обрђза́ти, обрђзаю несвршени, уз различиту промену (СРЯ, XII, 149), док се у другом разлика огледа у промени, при чему нису акцентовани староруски глаголи, већ њихови облици на савременом руском језику: обрђзати ${ }^{1}$ обрђжоу, -жеть: 1. отре́зать от чего-л., обре́зать что-л., обрђзати ${ }^{2}$ обрђзаю, -єть: 1. отреза́ть от чего-л., обреза́mь что-л. (СДРЯ, V, 540-541), а тако је и у старословенском језику ${ }^{30}$ (Стсл, 398). И. И. Срезњевски, међутим, за исти глагол са променом обрђзаю наводи само значење несвршеног вида (Срезневский, II, 553).

\footnotetext{
${ }^{29}$ Види н. 21.

${ }^{30}$ Наводи се само значење совершить/совершать обряд обрезания.
} 


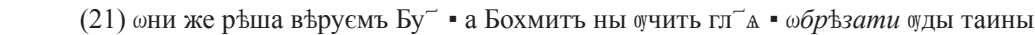
- и свинины не сти • (ПВЛ, 84)

(21a) А они рекоше: „Вјерујемо у Бога, а Мухамед нас учи, говорећи: да обрезујемо уде тајне, да свињетине не једемо, [...]” (ПМљ, 53)

У наведеном примеру анализирани глагол има значење несвршеног вида, као што нам показује превод на српски језик. Руски преводиоци употребили су именицу обрезание у конструкцији са глаголом несвршеног вида: совершать обрезание (ПВЛ ДЛ, 176; ПВЛ ОТ).

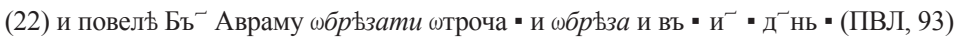

(22а) И заповједи Бог Авраму да обреже дјечака, и обреза га 8-ог дана. (ПМљ, 58)

У наведеном примеру староруски аорист и инфинитив су свршеног вида, на шта нам указује и превод на српски језик. Руски преводиоци су за инфинитив разматраног глагола употребили конструкцију са глаголом свршеног вида: совершить обрезание, а аорист су превели обликом: обрезали/обрезал (ПВЛ ДЛ, 180; ПВЛ ОТ).

Ни код глагола зарђзати нису уједначене лексикографске интерепретације, па се тумачи само као свршени - зарђзати, заръжоу, -жеть: зарезать; принести в жертву ${ }^{31}$ (СДРЯ, III, 343-344), затим се одваја у две јединице, па је прва свршеног вида: заре́зать, а друга несвршеног: зареза́ть (CРЯ, V, 287). И. И. Срезњевски исти глагол такође одваја у две лексикографске јединице, те за прву, уз промену заръж даје објашњење: убить ножемъ, док за другу не наводи објашњење, већ само промену зарђзаю (Срезневский, I, 945). Аорист наведеног глагола са значењем свршеног вида посведочен је и у ПМВ:

(23) поваръ же Гльбовъ именемь Торчинъ • вынезъ ножь зарђза Гльба • акы агнА непорочно - (ПВЛ, 136)

(23а) А кувар Гљебов, по имену Торчин, извукавши нож, закоље Гљеба, као јагње непорочно. (ПМљ, 85)

Српски преводилац употребио је презент свршеног вида, док би аорист гласио закла. У истом контексту, у староруском тексту глагол зарызати наведен је у форми инфинитива, такође са значењем свршеног вида: повель вборзь зарђзати Глґба. Руски преводиоци употребили су облик зарезал (ПВЛ ДЛ, 198; ПВЛ ОТ).

Напомена. У оквиру семантичке реконструкције Луче микрокозма П. II Петровића-Његоша Р. Маројевић (2016: 342-347) анализира глаголе несвршеног вида са дијалекатском суфиксалном алтернацијом -а́ва-/-а̀ј- (избјежа́вати: избјежа̀jȳ; пружа́вати: пружа̀је; ишчеза́вати: ишчеза̀jӯ; изрига́вати: изрига̀jӯ,

${ }^{31} \mathrm{У}$ истом речнику глагол зарђзывати се одређује као несвршени: резать, приносить в жертву (СДРЯ, III, 344). 
развија́вати: развија̀jӯ, препита́вати: препита̀jӯ, вјенча́вати се: вјенча̀је се, умоља́вати: умоља̀јуे, ублажа́вати: ублажа̀је, пружа́вати: пружа̀јеш, задржа́вати: задржа̀је) који су настали по аналогији с префиксалним глаголима несвршеног вида са коренима зна- и $\partial a$-. Разлику између свршеног и несвршеног вида аутор објашњава прозодијском творбом ${ }^{32}$, која у наведеним примерима има обличку функцију. Наиме, свршени вид глагола прѐдати у 3 . лицу множине има облик прѐдајӯ, док је у форми несвршеног вида акценат на следећем слогу преда̀јӯ. Позивајући се и на стање у савременом руском књижевном језику (узна́ю - просто будуће време глагола свршеног вида, узнаю́ - садашње време глагола несвршеног вида), аутор даље наводи да је реч о дијалекатском архаизму.

\section{4. ЗАКЉУЧНА РАЗМАТРАњА}

У нашем истраживању размотрили смо употребу староруских глагола код којих категорија вида није била јасно изражена, тј. у једним примерима имали су значење несвршеног, а у другим свршеног вида. У неким примерима иста категорија уско је везана за акценат, док нам у другим контекст открива одговарајуће значење. Српски језик омогућава нам не само увид у категорију глаголског вида, већ и времена, док је руски језик ограничен само првом категоријом. За главне облике на којима смо утврђивали једно од два могућа значења, тј. несвршени или свршени вид, узети су имперфекат и аорист, чиме смо указали на блискост староруског и српског језика, а тиме и на важност њиховог упоредног проучавања.

\section{ЛИТЕРАТУРА}

Ван Вијк 1962: Н. Ван-Вейк: О происхождении видов славянского глагола, у: Вопросы глагольного вида, Москва: Издательство иностранной литературы.

Грицкат 1957-1958: И. Грицкат, О неким видским особеностима српскохрватског глагола, Београд: Јужнословенски филолог, XXII, 65-130.

ИГРЯ 1982: Историческая грамматика русского языка. Морфология. Глагол (под ред. Р. И. Аванесова, В. В. Иванова), Москва: Наука.

\footnotetext{
${ }^{32}$ Исти аутор прозодијску творбу или преакцентуацију објашњава као „самостални творбени поступак у коме је промјена акцента обавезна а творбена база и њоме мотивисана новоформирана ријеч остају у истој врсти ријечи и са истим типом промјене, при чему се формира нова ријеч без кидања семантичке везе између мотивне ријечи и творенице” (Маројевић 2016: 399).
} 
Маројевић 2008: Р. Маројевић, Пјеснички језик Његошев. II (Перфективни глаголи с имперфективним ликом), Београд: Научни састанак слависта у Вукове дане, 37/1, 2008: 179-198.

Маројевић 2016: Р. Маројевић, Луча микрокозма. Критичко издање. Текстологија. Редакција и коментар Радмило Маројевић. Подгорица: ЦИД, Цетиње: Narodni muzej Crne Gore.

Маслов 2004: Ю. С. Маслов, Возникновение категории совершенного/несовершенного вида, $y$ : А. В. Бондарко, Т. А. Майсак, В. А. Плунгян (ред.), Избранные труды. Аспектология. Общее языкознание, Москва: Языки славянской культуры, 131-140.

Ружичка 1962: Р. Ружичка, Глагольный вид в „Повести временных лет”, у: Вопросы глагольного вида, Москва: Издательство иностранной литературы.

Симина 1959: Г. Я. Симина, $K$ вопросу об употреблении глагольных форм промедшего времени в «Повести временных лет по Лаврентьевскому списку», Исследования по грамматике русского языка, II, Ленинград: Издательство Ленинградского университета.

Спасојевић 2015: М. Спасојевић, Двовидски глаголи у савременом српском језику, докторска дисертација, Београд: 2015.

\section{ИЗВОРИ}

ОССРК 1994: В. Минић, Одабране странице старе руске књижевности, Цетиње: Обод.

ПВЛ 21962: Повесть временных лет, у: Полное собрание русских летописей. Том первый. Лаврентьевская летопись и Суздальская летопись по Академическому списку, Москва: Издательство восточной литературы.

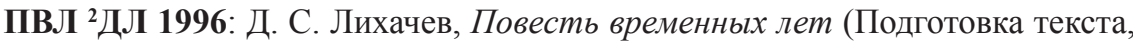
перевод, статьи и коментарии Д. С. Лихачева), Санкт-Петербург: Наука.

ПМљ 2003: Н. Косовић, Повијест минулих љета или Несторов љетопис, Београд: ИКП Никола Пашић.

ПВЛ ОТ: Творогов О. В., Повесть временных лет, 〈http://lib.pushkinskijdom. $\mathrm{ru} /$ Default.aspx?tabid=4869> 8.05.2016. 


\section{РЕЧНИЦИ}

PMC 1990: Речник српскохрватскога књижевног језика, I-VI (Друго фототипско издање), Нови Сад: Матица српска (I-III и Загреб: Матица хрватска).

RJAZU 1892-1897；1918；1930；1931；1933；1953；1958；1972: Rječnik hrvatskoga ili srpskoga književnog jezika, IV, VIII/35, VIII/36, X/45, $\mathrm{X} / 46, \mathrm{XI} / 48, \mathrm{XIII} / 56, \mathrm{XIII} / 58, \mathrm{XVI} / 70, \mathrm{XX} / 86$, Zagreb: JAZU.

РСАНУ 1962; 1975; 2001: Речник српскохрватског књижевног и народног језика, II, IX, XVI, Београд: САНУ.

СДРЯ 1988; 1990; 1991; 2000; 2002; 2004; 2013: Словарь древнерусского языка XI-XIV вв, I, III, IV, V, VI, VII, X, Москва: Русский язык/ Азбуковник.

СРЯ $1975 ; 1978 ; 1979 ; 1980 ; 1986 ; 1987 ; 1989 ; 1990 ; 1991 ; 1997 ; 2008$ : Словарь русского языка XI-XVII вв, II, V, VI, VII, XI, XII, XV, XVI, XVII, XXII, XXVIII, Москва: Наука.

Срезневский 2003: И. И. Срезневский, Материаль для словаря древнерусского языка, I-III, Москва: Знак.

СРНГ 1977; 1996; 2001: Словарь русских народных говоров, XII, XXX, XXXV, Ленинград/Санкт-Петербург: Наука.

Стсл 1994: Старославянский словарь (по рукописям X-XI веков), под ред. Р. М. Цейтлин, Р. Вечерки и Э. Благовой, Москва: Русский язык.

ТСРЯ 2007: Толковый словарь русского языка с включением сведений о происхождении слов (отв. ред. Н. Ю. Шведова), Москва: РАН.

ЭССЯ 1983: Этимологический словарь славянских языков. Праславянский лексический фонд, IX, Москва: Наука.

\section{О НЕКОТОРЫХ ДРЕВНЕРУССКИХ ДВУВИДОВЫХ ГЛАГОЛАХ}

\section{Резюме}

В настоящей работе на материале «Повести временных лет» рассматривается категория вида тех глаголов, у которых она не дифференцировалась. Таким образом, с одной стороны, некоторые приставочные глаголы в эпоху древнерусского языка входили в видовые пары, в то время как другим значение вида определялось контекстом. Древнерусские формы имперфекта и аориста можно реконструировать 
благодаря сложной системе прошедших времен в современном сербском языке, чем подчеркивается значение сопоставительного изучения двух языков.

Ключевые слова: вид глагола, имперфект, аорист, древнерусский язык, сербский язык.

В. Б. Вишневаи 